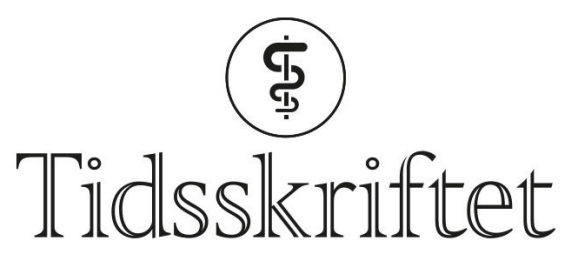

DEN NORSKE LEGEFORENING

\title{
Hva bør Norge gjøre politisk for å fremme amming?
}

KOMMENTAR

\section{SIGVE BROUWER}

E-post: Sigve.brouwer@gmail.com Sigve Brouwer er politiker for Miljøpartiet De Grønne. Ingen oppgitte interessekonflikter.

Jeg er helt enig med medisinsk redaktør Martine Rostadmo i at amming er et godt folkehelsetiltak (1), og norske helsemyndigheter anbefaler jo amming det første året. Det er forkastelig at selskaper som Nestlé driver aggressiv markedsføring av morsmelkerstatning i land med urent vann, hvor det har ført til dødsfall og sykdom. Det er for meg imidlertid litt uklart hva redaktøren mener Norge bør foreta seg politisk?

\section{LITTERATUR:}

1. Rostadmo M. Amming som globalt folkehelsetiltak. Tidsskr Nor Legeforen 2018; 138: doi: 10.4045/tidsskr.18.0432. [CrossRef]

Publisert: 17. september 2018. Tidsskr Nor Legeforen. DOI: 10.4045/tidsskr.18.o669

(C) Tidsskrift for Den norske legeforening 2020. Lastet ned fra tidsskriftet.no 